\title{
Study on the Political Participation of Chinese Rural Christian Believers
}

\author{
Li Xuejiao \\ College of Humanities and social development \\ Northwest A\&F University \\ Yangling, Shanxi, PRC \\ 948258435@qq.com
}

\author{
Wang $\mathrm{Na}$ \\ College of Humanities and social development \\ Northwest A\&F University \\ Yangling, Shanxi, PRC \\ 632187055@qq.com
}

\author{
Liu $\mathrm{Yi}^{*}$ \\ College of Humanities and social development \\ Northwest A\&F University \\ Yangling, Shanxi, PRC \\ liufulaiya@163.com \\ Li Xuejiao and Wang Na contributed equally to this work
}

\begin{abstract}
A number of research survey shows there are more and more Christian in Chinese rural areas. The main purpose of this paper is to find out dose the rural Christian believers' faith has impact on their behavior in the political participation, so we establish a system to measure whether the Christian faith of rural Christian believers has an impact on their political participation, and in which way the faith influence rural Christian political participation. That is the first time we do the research on religion start with measure the relationship between political participation and faith. According the results we have reason to believe that faith have complicated influence in political participation and deep-seated impact on the Chinese grassroots regime.
\end{abstract}

Keywords-Political participation; Christianity; Grass roots political power; Rural area

\section{Statement of Problem AND Literature ReVieW}

\section{A. Research on the Origin}

When Jesus said, "Pay to Caesar what belongs to Caesar and God what belongs to God[1]", it opened the tradition of separation of church and state. On the stage of history, religion and politics have an extremely ambiguous relationship[2]. At very low productivity, people have no way to find a more reasonable way to resolve depressed and explain the paranormal, religion was the greatest and only comfort. Largescale development of religion usually occurs in big turmoil, including natural disasters such as earthquakes, floods, droughts, as well as war and other major events will make local religion have a very big development. Throughout history, many countries in the very long or short period of time have a variety of contact with religion. Christianity was persecuted from the beginning to the last to be recognized as the state religion of the West. These are worthy of us to rethink the place of religion.

\section{B. Concept Definition and Literature Review}

Christianity in China, especially in rural area has developed rapidly, what kind of influence this station will bring to grassroots politics is main discussion in this paper.

The so-called political participation, it refers to a variety of individuals and social groups to actively participate in the political processes that affect their lives, is personal goals affect the actual results of government policy, and citizens to freely express their political will to achieve civil and political rights' important form[3][4].

But checking the past literature, we found that faith itself is a very private thing, but once we joined a religion is bound to bring a range of effects for our lives. Every man is a social person, political life is an integral part of social life, whether more or less willing or unwilling will participate. Grassroots democracy has been the focus of the study as well as hot, but when talking about political participation, the rural masses will be studied as a whole, and again subdivided rural masses, scholars generally from sex, for example, "Rural women in the New Political Participation [D]. Capital Normal University”[5], System in Rural Areas under Autonomous Woman's Political Participation [6]", or another striking groups of migrant workers, like "Study on rural political participation of rural migrant workers"[7], almost no "faith" as the division of political criteria from the study population, this is a political research area has been vacant. We hope to attract valuable comments, makes more and more in-depth research in this field is initiated through this article.

Therefore, how to achieve an orderly political participation of Christians in rural areas is to achieve its fundamental political rights and protect their legitimate rights and interests' institutional safeguards. And explore the deep-seated reasons affect political participation of Christians in rural areas, is a 
prerequisite to effectively guide the rural Christian political participation[5].

In this paper, we intend from the perspective of rural Christian faith experience, and explore its impact on the consciousness of political participation, electoral behavior and political interest demands action.

\section{STUDY DESIGN}

In order to be able to more clearly understand the Christian influence on villagers' political participation, we investigating believers collected from villages in yangling (rural town of Shaanxi province) region, in order to make the result more scientific and effective, we set the believers and religious believers (Religious believers from different villages, we selected the greatest number of religious believers do research of the village) in the control group to observe, experiment.

\section{THE INVESTIGATIVE PROCESSES}

This research use the data from the Northwest Agriculture and Forestry University, national key project "the GuanZhong rural Christians to participate in the rural public life behavior research" sampling questionnaire, the survey sampling range for Shaanxi GuanZhong area.

The survey sampling range is the Shaanxi province GuanZhong rural Christians, survey implementation time for October 2014 in April 2016.

Sampling concrete consists of two steps: First, according to the simple random sampling method to extract two samples county (city, area) from the GuanZhong area in Shaanxi province; second, according to the random sampling method to obtain samples of each county (city, area), random respectively three towns, received 6 samples of villages and towns; And then randomly selected randomly from the villages and towns in the a parish, altogether six parish in smoke; finally, have drawn six parish as sample unit, randomly selected in each township 100 rural Christian faith, it received 600 families. The second step USES the household survey method, from more than 600 peasant families in various random 1 farmers Christians as the research object, If a family has more than one farmer Christians, by method of birthday (July 1, the closest) extraction.

The 498 access object is the Christians sample questionnaire survey of farmers. (Early in yangling area). The survey questionnaires out of 500, 489 effective questionnaires were taken back, effective questionnaire recovery rate was $97.8 \%$.

\section{CONCLUSION AND DISCUSSION}

Based on the survey of 489 rural Christians in the GuanZhong region of Shaanxi province, we found that the political participation of rural Christian group status present different difference, The establishment of rural Christians economic main body status and seek economic benefit protection mechanism is the basic dynamic of farmers' political participation and motivation, "Instrumental rationality" rather than "value rationality" is the political participation of rural
Christian action logic. In particular, tend to be more economic responsibility of men, medium of cultural quality of socioeconomic status and beliefs center will have greater political participation at the grassroots level more into political elections and interests demands of practice.

\section{A. In general, the political participation of rural residents is low.}

It can't be denied that believing in Christianity doesn't have a significant influence on rural residents in part of political participation .On the whole, it shows a low level. Since the rural people participating in politics is universal and rare on the present that whether they have a belief or not cannot change how the overall environment affects them.

However, after reading previous literature and doing researches we found that rural residents' political participation took an ascend trend recently. There's no doubt that the government has made great efforts, including launching campaigns and popularizing political knowledge, but aimed at rural Christians who were 35 to 55 years old more, and they behaved more active in participating in politics. There's a strong relationship between the aggrandizement of education and the rise of political rights and participation consciousness.

\section{B. The promotion of faith to political participation}

During investigations, we also discovered that believes had some other unexpected positive influences to our society that we've never thought of before we did these surveys. Sometimes, Christians are more likely to obey rules than other people and part of them are active in political participation. There's a sentence in Christian doctrine said that God's return to God, Kaiser Kaiser. When asked Mrs. Zhang, who is a 52-year old Christian, how did she choose if there's an activity hold by the church and another was conducted by the village committee, she stressed she wouldn't give up either of them because the church choose the day time as for activities time and the village committee made nights to have meetings or other things in general. Therefore, she participated in both of them. We also have heard such remarks from some other people.

Besides, we need to take more attention to that Christians are rejuvenated for the statistics showed Christians aged 18 to 30 are 21.2 percent in whole Christians, and who are 21 to 50 years old are 39.7 percent, they're significantly higher than our consumptions.

\section{The bad effects of belief take to political participation}

On the other hand, what should also be paid attention to is that the faith does harm people's political participation in some way. For instance, people cannot make a distinction between the religion and heresy that causes management and guide more difficult. Besides, it may leads negative emotions even aggressive violence and contributes to a breakdown in order and so on.

The Christian doctrine makes a difference between people. As the bible says: "Some of them are God's sons, when the Jesus comes for the second time they would be elected and the other are abandoned, thus they are doomed to go to the hell 
eventually" [8]. In real life, the church not only teaches people spread gospel to others, but also lets them be away from pagans and cut off from them. To a great extent, coming into the church and being sympathetic to it causes most people have to drop from their old interpersonal relationship networks and enter another entirely new networks. Though people are made a difference in religion, they can never be taken apart in daily life. However, as far as their friends are concerned, there's a distinction.

While we did investigations, some person who were in charge of the churches told us the local government often did examinations on their activities at first, but as time went by, they hardly did those. In addition, some people said their relatives took part in activities called "Eastern lighting" which were cult but not religious activities actually.

The governments of rural areas regulating activities of religious shows a polarization that is either relaxing or sensitive. A better management system is in need. In the meantime, the Central Document NO. 19 in 1982 expressed cadres of the party and government were supposed to support and encourage religious organizations to solve their problems rather than instead of them. While there were some local governments intervened directly[9]. Apart from that, the party thought of the religious things important and insisted we should treat religion correctly by patriotic religious organizations. According to the leaders' point of religious problems should be solved when they were in the bud, local officials took comprehensive measures in an oversimplified and crude way.

There is no specific law on religious practices[10]. Until now, there haven't regulations placed clear what were normal and what weren't although one of law in our constitution said our country protected normal religious activities. Therefore, local governments don't know what kind of activities can be allowed either. The perennial dilemmas between Christians and the local governments not only made them distrust each other, but also blocked normal political participation.

\section{REFERENCES}

[1] New Testament ,the Holy Bible ,New Testament Version .2008

[2] Xu Cheng. Proverbs - Reflection of Influence of the Holy Bible on Western Culture[J]. Overseas English,2012,16:279-282.

[3] Wu Licai, Zhang Liang. The spiritual belief of farmers: lack or transformation -- Reflection on the prevalence of Christian culture in rural areas [J]. Journal of humanities, 2010,02:175-180.

[4] Sun Xiong, Huang Jia. The development trend of Rural Christianity and its social influence -- Based on the research of Zhejiang [J]. Journal of provincial Party School of Zhejiang Provincial Committee of CPC, 2011,06:117-124.

[5] Zhang Jiazhi Rural women in the New Political Participation [D]. Capital Normal University, 2009.

[6] Xiong Wei. System in Rural Areas under Autonomous Women's Political Participation [D]. Guangxi Normal University, 2014.

[7] Wang Xinliang. Study on rural political participation of rural migrant workers [D]. Qufu Normal University, 2009

[8] New Testament ,the Holy Bible ,New Testament Version .2008

[9] Research Institute of rural development, China Academy of social sciences research group. The behavior logic of rural political participation [J]. China Rural observation, 2011,03:2-12.

[10] Li Xiangping "society" and "legal persons" Double Construction Contemporary Religious Policy and Management System Reform Roadmap China [J] Shanghai University (Social Science Edition), 2015,02: 1-24. 